Johnson, F. R. (1955). Private communication.

Khruschov, N. S. (1956). Report of the Central Committee to the 2oth Congress of the Communist Party, Moscow. Feb. 14, 1956, p. 37. London: Soviet News.

Lantz, A. W. (1947). Progr. Rep. Pacif. biol. Sta. no. 73, p. 58.

Lantz, A. W. (1948). Progr. Rep. Pacif. biol. Sta. no. 77, p. I 44.

Ministry of Agriculture, Fisheries and Food: National Food Survey Committee. (1956a). Studies in Urban Household Diets I 944-1 949. London: H.M. Stationery Office.

Ministry of Agriculture, Fisheries and Food: National Food Survey Committee. (1956b). Domestic Food Consumption and Expenditure 1954. London: H.M. Stationery Office.

Ministry of Agriculture, Fisheries and Food: National Food Survey Committee. (1957). Domestic Food Consumption and Expenditure 1955. London: H.M. Stationery Office.

Ministry of Agriculture, Fisheries and Food: National Food Survey Committee. (1958). Domestic Food Consumption and Expenditure 1956. London: H.M. Stationery Office.

Ministry of Food: National Food Survey Committee. (1953). Bull, Minist. Fd, Lond., no. 723, p. 8.

Myles, W. H., Reay, G. A. \& Farrer, H. E. M. (1945). Certain Aspects of the German Fishing Industry. British Intelligence Objectives Sub-Committee Final Report no. 493. London: H.M. Stationery Office.

Reay, G. A. (1951). Chem. \& Ind. p. гог9.

Shakespeare, W. (I598). Henry IV, Part I, ii, 4, 247.

Shewan, J. M. \& Ehrenberg, A. S. C. (1957). F. Sci. Fd Agric. 8, 227.

White Fish Authority. (1956), Report on Enquiry into the Costs of Distributing White Fish. London: White Fish Authority.

Woodham, A. A. (1958). Proc. Nutr. Sac. r7, 142.

\title{
The use of fish flours as human food
}

By The Nutrition Division, Food and Agriculture Organization of the United Nations, Rome, Italy

The prevalence of protein malnutrition in many parts of the world has been established during recent years. Its prevention depends on increasing the supply and consumption of proteins of appropriate nutritive value. Fish is among the important sources of such proteins and in many countries in which protein malnutrition is common there are great possibilities for expanding the fishing industry, depending not only on greater catches or yields, but also on better facilities for preservation, transport and marketing. At present frozen and canned fish are in general too expensive to be within the means of the mass of the people, though there are possibilities of developing cheaper forms of canning. Traditional methods of preserving fish, such as drying, smoking and curing, are widely used, but often do not secure a long storage life; here again there are possibilities for improvement which require investigation. All these approaches are of importance in increasing fish supply and consumption. There is still room, however, for the method discussed in this paper, namely the production of edible fish flour, to which the FAO Nutrition Division has devoted considerable attention.

The proteins of fish muscle are equivalent in biological value to those of animal muscle and milk. Fish flour, properly processed, retains the biological value of the original material. It keeps well and can without much difficulty be incorporated into local foods and dishes.

17 (2) 4 
Fish meal for animal feeding is already produced on a large scale in many countries. A method of approach has been to encourage firms manufacturing fish meal to introduce processing methods which can produce, instead of crude fish meal, refined fish flour of high biological value fit for human consumption. Work in this field has been done in collaboration with the FAO Fisheries Division and with WHO and UNICEF. WHO has set up a Protein Advisory Group which studies, by appropriate methods, protein-rich foods for supplementing the diets of children and mothers and advises on their suitability for human consumption from various points of view; both FAO and UNICEF are associated with this Group. With respect to fish flour and other foods, UNICEF has provided funds to procure material for testing and for acceptability trials. It has helped the Government of Chile to set up a plant to produce edible fish flour, based on a series of investigations concerned with processing, biological value and acceptability, and is prepared to support similar projects elsewhere.

This work on fish flour is part of a broader programme to develop the use of suitable protein-rich foods to prevent protein malnutrition.

\section{Types of edible fish flours}

Potential consumers can be divided into two groups: (a) those preferring flour with a mild fishy flavour or no flavour, and (b) those preferring rather strong fishy flavours, being used to highly flavoured fish products such as fish pastes and sauces. Where the former preference prevails, suitable processing to remove undesired smell and flavour is needed, and flour so processed can often be consumed by admixture with bread flour. In countries in which strong fish flavours are appreciated deodorization and 'flavour refining' are unnecessary, and the fish flour should resemble, in taste and flavour, local fish products, unfamiliar flavours being generally unacceptable.

\section{Criteria for the use of fish flour in human nutrition}

These relate to nutritive value, bacteriological purity, toxicity, acceptability and cost.

Nutritive value. Fish flours should be regarded as a protein supplement to local diets, consumed in relatively small amounts. They must, therefore, be rich in protein of high biological value, and any impairment in biological value during processing must be avoided.

Bacteriological purity. Bacterial content must be low, especially when the flour is for young children. The presence of Clostridia and Coliforms cannot be tolerated. The raw material for processing, whether fresh fish or fish meal, must therefore reach acceptable standards of bacterial purity, of a different order from those required in the manufacture of fish meal for animals. Solvent-extracted flours, especially deodorized flours, usually have a low bacterial count immediately after processing, but sanitary precautions are needed in subsequent handling to prevent contamination. Flours that are not defatted and deodorized will always present 
bacteriological hazards if the raw material has a high bacterial count, however careful and sanitary the processing.

Toxicity. Fish meals of good commercial quality have been widely fed to animals without toxic effects. Fish flour is therefore unlikely to be toxic to human beings, particularly when taken in small amounts. This conclusion, however, needs some qualification. Oxidized unsaturated fatty acids, peroxides and polymerization products are found in some fish meals, but proper processing, in which high temperatures are avoided and exposure to air minimized, will prevent such changes to a large extent. Most fish meals of good commercial quality have a low fat content, and in refined defatted fish flours fat content is usually far below $\mathrm{I} \%$.

A possible source of toxicity may be histamine, or other active amines, that can be formed by bacterial action in fish products during putrefaction. Being decomposed in the intestinal tract, histamine is, however, toxic only in large quantities when taken by mouth.

The possible toxic effects of solvent residues and solvent impurities must be borne in mind, but in practice there should be little difficulty in avoiding this hazard.

Acceptability. Unfamiliar foods tend to be regarded with suspicion and distaste. Acceptability trials are therefore an essential part of any project to introduce fish flour into a country. In designing these, attention must be given to food habits and prejudices, and appropriate means of incorporating the flour in foods and dishes devised.

Cost. Account must be taken of certain factors with a bearing on the cost of fish flour. The raw material should be obtainable locally in abundance, or at least there should be good prospects of developing its production. Appropriate processing facilities should be available, or possibilities exist for establishing these on a reasonably economical basis. The cost of fish flour imported from abroad will naturally tend to be higher than that of locally produced flours, but the needs of one country might in certain circumstances be met by flour produced cheaply on a large scale in another. The general statement that the cost of the flour should be in line with the purchasing power of the consumers is in itself somewhat meaningless, but can be interpreted in the light of local conditions. A rough indication may be that the price of fish flour should be equivalent, on a unit weight basis, to that of imported dried skim milk, which has been widely and successfully used as a dietary supplement.

\section{Manufacture of edible fish flour}

Non-deodorized edible fish flours can be products corresponding to fish meals for animal feeding, but manufactured by low-temperature reduction processes and with appropriate sanitary precautions. Part or most of the fat present in the raw material must be removed, in accordance with the kind of fish used for processing. Meals containing $4-8 \%$ fat may be satisfactory from the public-health standpoint, if made from fresh sound fish with effective sanitary control and stored in airtight 
containers for not more than a few months before consumption. In such circumstances the possibility that harmful effects may result from oxidized or other altered components of fat is small. As low a fat content as is economically practicable is, however, preferable. Fat can be removed by solvent extraction. Experience has shown that repeated and prolonged treatment with solvents such as light petroleum and ethanol does not significantly affect biological value and digestibility.

Deodorized, flavourless or almost flavourless, fish flours can be prepared by several methods. Only a few of these, however, seem to produce a sufficiently effective and lasting 'deflavouring' effect (that is, yield a flour unsusceptible to 'flavour reversion'), without being too costly. Deodorized fish flours can be most easily made by processing minced wet fish directly. High-grade fish meals can sometimes be conveniently and economically used as raw material for the production of refined flour, but it is more difficult to remove unacceptable flavours from fish meal than from wet fish.

With FAO co-operation, three promising processes for manufacturing defatted and deodorized fish flour have been developed. One of these--for which a Swiss company, Dabsch \& Co., is responsible--involves azeotropic extraction with light petroleum followed by repeated washings with ethanol for deodorization. This process produces an almost flavourless fish flour either from fresh fish or from fish meal of high quality. The pilot fish-flour plant supported by UNICEF in Chile was designed and installed by Dabsch. The biological and chemical investigations and the acceptability tests needed in developing this product were organized by FAO.

A second process is that of a German firm, Emil Vogel A.G. This is mainly a deflavouring and deodorizing process, operating on the principle that defatting and drying can be done by any of the conventional methods, azeotropic or other, with ethanol or acetone as solvents. The refining itself is based on alkali or acid treatment of the defatted raw material, the alkali $(\mathrm{NaOH}$ or $\mathrm{KOH}$ ) or the acid $(\mathrm{HCl})$ being added with ethanol or acetone. The final washings are made with ethanol or acetone alone and the drying is carried out at reduced pressure. The product yielded has a high biological value. Here again FAO was responsible for biological and chemical control and acceptability trials.

The third process, followed by the VioBin Corporation, U.S.A., is based on azeotropic solvent extraction with ethylene dichloride, followed by washing with ethanol.

Other processes of an approximately similar nature have been developed in South Africa and Morocco.

\section{Investigation and control of the final product}

Concurrently with technological work on processing, studies of the nutritive value of flours and other relevant matters have been undertaken, through a coordinated programme of research and testing for which FAO, WHO and UNICEF are jointly responsible. In 1956 , the Rockefeller Foundation made a grant of $\$ 250,000$ for work on the testing and development of protein-rich foods, this being 
administered by a committee of the (U.S.A.) National Research Council, with which FAO, WHO and UNICEF are associated. Part of the grant has been used for studies of fish flour, supplemented by UNICEF funds allotted for the procurement of material for testing. The co-operation of a number of laboratories in various countries has been secured. Through these activities, useful information has been obtained. It should be observed that the findings presented relate to batches of flour prepared on an experimental scale and not in commercial manufacturing plants.

Investigations have been concerned largely with the following:

Chemical composition and bacterial contamination. The Central Institute for Nutrition Research (Central Technisch Instituut T.N.O.), Netherlands, has undertaken chemical analyses and bacteriological tests, the former relating mainly to protein, fat, ash and moisture. The protein and ash content of the defatted flour, on a dry basis, depends largely on the raw material used and how it is handled. The protein content, on a wet basis, of flour prepared by the three processes referred to above, was from 66 to $87 \%$. Ash varied from $3.1 \%$ in fish flour made from fillets to $24.8 \%$ in flour made from whole degutted fish. Fat ranged from 0.22 to $0.60 \%$.

Bacterial contamination has presented no problems. The bacterial count of the flours was usually in the range of from 100 to 1000 per gram, whereas that of any crude fish meals used as starting material was over 140,000 per gram. Non-deodorized flours prepared by the Harcourt Butler Institute of Public Health in Rangoon from small freshwater fish and tested in the Institute showed a low bacterial plate-count and a complete absence of Coliforms, but Clostridia were present. During acceptability trials with these flours, no gastro-intestinal disturbances were noted.

Biological value. Biological assays to determine protein utilization and the digestibility coefficient, and hence 'biological value', have been undertaken for FAO by Dr A. E. Bender in the laboratories of Bovril Ltd in the United Kingdom. The net protein utilization (N.P.U.) has been determined by the method of Bender \& Miller (1953) and Miller \& Bender (1955). Table I shows the biological values of representative fish-flour samples produced mainly by the three processes previously described. N.P.U. values range from $\mathrm{I} 8$ to 80 and digestibility coefficients from 47 to 97 . It should be noted that the low figures were given by fish meals and flours tested at an early stage in the programme, and that, after the determination of such unsatisfactory values, improvements in technique were introduced by the manufacturers. With flours now produced, the digestibility coefficient is about 95 and the N.P.U. ranges from 64 to 78 ; the biological value of the best flours is between 67 and 80.

Tests of nutritive value and safety with laboratory animals. Experimental work on fish flour with laboratory animals is being conducted by Dr J. B. Allison and his colleagues at Rutgers University, New Brunswick, New Jersey, U.S.A., financed by Rockefeller funds. In experiments with rats lasting I year, refined defatted and deodorized flour prepared by the Dabsch process was compared with non-deodorized fish meal and casein. The nutritive value and safety of these fish products were 
assessed by growth records, blood determinations, and the histological and pathological examination of organs and tissues. In addition, biological values were determined with dogs by a nitrogen-repletion method. The studies with rats, now completed, showed that the flours had a nutritive value equivalent to that of casein. The experiments with dogs, still in progress, have indicated that the biological value of refined Dabsch-processed flour is similar to that of lactalbumin.

The value of fish flour as a protein supplement to diets based largely on cereals has been studied by numerous investigators. Its effectiveness for this purpose is now generally accepted.

\section{Evaluation of processing methods}

Further work is needed to assess the effectiveness of the various important processing methods, with reference to both nutritive value and the economic aspects of production. In 1957, UNICEF requested the Food Technology Department of the Massachusetts Institute of Technology to undertake a study of these

\section{Table 1. Biological value of defatted and deodorized fish flours}

(Results obtained by A. E. Bender, Bovril Ltd, London)

\begin{tabular}{|c|c|c|c|c|c|c|}
\hline Raw material & $\begin{array}{c}\text { Protein } \\
(\%)\end{array}$ & $\begin{array}{c}\text { Minerals } \\
(\%)\end{array}$ & $\begin{array}{l}\text { Fat } \\
(\%)\end{array}$ & N.P.U. & Digestibility & $\begin{array}{l}\text { Biological } \\
\text { value }\end{array}$ \\
\hline Lean fish & $70 \cdot 2$ & 24.8 & $0 \cdot 3$ & 49 & 93 & 53 \\
\hline Cod & $74^{\circ} \circ$ & $22 \cdot 6$ & 0.1 & 65 & 95 & 69 \\
\hline Cod fillets & $89 \cdot 1$ & $4 \cdot 4$ & 0.2 & 64 & 95 & 67 \\
\hline Herring & $87 \cdot 0$ & $3 \cdot 1$ & 0.3 & 74 & 93 & 79 \\
\hline Lean fish & $75 \cdot 2$ & 13.5 & 0.3 & 73 & 93 & 78 \\
\hline Lean fish & 647 & $24 \cdot 8$ & $I \cdot 2$ & 77 & 94 & 82 \\
\hline Lean fish & $71 \cdot 3$ & $24 \cdot 8$ & $I \cdot 2$ & 77 & 96 & 80 \\
\hline Fatty fish & $72 \cdot 7$ & $2 \mathrm{I} \cdot 2$ & 0.1 & 29 & $8 I$ & 36 \\
\hline Fatty fish & $73 \cdot 4$ & 20.5 & 0.1 & 31 & 68 & 46 \\
\hline Fatty fish & $66 \cdot 6$ & 20.0 & $0 \cdot 1$ & 42 & 71 & 59 \\
\hline Semi-lean fish & $79 \cdot 4$ & 19.4 & $0 \cdot 1$ & 67 & 94 & 71 \\
\hline Semi-lean fish & $74 \cdot 7$ & 19.4 & 0.2 & 55 & 96 & $5^{8}$ \\
\hline Herring & 83.0 & 10.4 & 0.6 & 56 & 94 & 60 \\
\hline Sardines & $81 \cdot 8$ & $9 \cdot 6$ & 0.5 & 70 & 95 & 74 \\
\hline Gutted haddock & $73 \cdot 6$ & 19.0 & 0.2 & 69 & 95 & 73 \\
\hline Whole cod & $75 \cdot 7$ & $21 \cdot 6$ & 0.2 & 67 & 95 & 71 \\
\hline Cod & $78 \cdot 7$ & 14.9 & 0.3 & 64 & 95 & 67 \\
\hline
\end{tabular}

questions, providing appropriate financial aid. FAO hopes to collaborate by assigning to the Institute of 'Technology a research worker holding an FAO André Mayer Fellowship.

\section{Acceptability tests}

Obviously measures to introduce fish flour into a country should be initiated only when the flour can easily be added to local diets and consumed regularly without distaste for prolonged periods. During recent years, acceptability trials have been organized, with FAO assistance, along the following lines. First, preliminary trials are made with a limited number of people, often members of the staff of a 
research laboratory, to eliminate products that have no chance of acceptance, and to devise suitable recipes. These are followed by trials on a larger scale, usually involving 50-200 children, in which 'enriched' food preparations containing fish flour are given daily for $\mathbf{I}-2$ months or longer. In some instances edible fish flours provided by FAO and UNICEF have been used in hospitals for testing their effect in treating protein malnutrition in children.

The amount of fish flour consumed daily by children as a supplementary food rich in protein may be from Io to $\mathrm{I} 7 \mathrm{~g}$, supplying 7-12 $\mathrm{g}$ protein. Amounts of this order have been given in the acceptability trials. They may be compared with $30-40 \mathrm{~g}$ of dried skim milk, supplying IO-I $3 \mathrm{~g}$ protein, given to children in most supplementary-feeding programmes supported by UNICEF.

To date, some thirty preliminary and twenty large-scale acceptability trials have been made. Institutes or individual workers in the following fifteen countries have been supplied with quantities of fish flour for this purpose: Belgian Congo, Brazil, Burma, Cameroons, Chile, Colombia, Ecuador, French Equatorial Africa, French Sudan, India, Mexico, Pakistan, Peru, Senegal, Turkey. Deodorized flours were provided for the trials in Brazil, Chile, Colombia, Ecuador, India, Mexico, Pakistan, Peru and Turkey.

Some of the earlier trials were discouraging, since the product used was not of high quality and had been stored for some time under poor conditions. For various reasons, mainly inadequate planning and supervision, some of the trials were not organized on a sound basis and according to a uniform pattern. Later trials have, however, in general been carried out in a satisfactory way.

The fish flours prepared by the improved processes are in general acceptable. In Chile, bread containing $7 \%$ of the flour was liked by children; a $10 \%$ admixture was also acceptable, but the colour of the bread was affected. In Ecuador and Peru, admixture in bread at the $10 \%$ level raised no difficulties. Workers conducting trials in India reported that fish flour is 'tasty and palatable when cooked with proper ingredients and vegetables. In curry powders it has a very nice taste'.

Burma is among the countries in which trials of non-deodorized fish flour have been made, the flour being prepared from small freshwater fish. Samples made by an FAO expert attached to the Harcourt Butler Institute of Public Health were given for long periods to children, pregnant and nursing women, and hospital patients in amounts of about $20 \mathrm{~g}$ daily. The results were successful. The flour has been added to Burmese soups, sauces and vegetable dishes and does not appear, when so taken, to produce an undesirable taste and flavour. It was appreciated when added to rice gruel eaten for breakfast. Some adults objected to finely ground fish flour because it felt chalky and gritty in the mouth. A coarsely ground fish flour with particles up to $\mathrm{I} \mathrm{cm}$ in length was liked because it resembled the small dried prawns commonly eaten in Burma as a garnish and cooked with fried foods.

Apart from acceptability trials with children of school age and adults, attempts are being made to test the digestibility and nutritive value of fish flour by observations on young children. In Senegal it has been found that fish flour is well digested by young children and appears to have a stimulating effect on growth. 
Though the trials have on the whole been promising, acceptance of fish flour by special groups supervised and encouraged by investigators does not necessarily imply that people will be ready to buy it and consume it as part of their ordinary diets. Popularization calls for the education of the public by government services, reinforced by commercial advertising on the part of manufacturers.

Fish flour has been successfully marketed in the Belgian Congo and Ghana, at first at a specially reduced price and later at a commercial price. Apparently there are prospects of increasing demand in these countries. In the Union of South Africa attention has been given to the question of popularization. Here fish flour has been produced independently of the FAO/WHO/UNICEF programme and attempts are being made to encourage its use as an ingredient in bread and mealie meal.

\section{Tentative specifications for edible fish flour}

Tentative specifications for solvent-extracted deodorized fish flour for human consumption, based on the available data and experience, are now being considered. Other types of fish flour may, however, require different specifications, as for example flour made by pressing, dehydration and grinding, with or without degutting and filleting. Specifications will also be needed for non-deodorized fish flours, in conformity with local processing facilities and methods of use.

Tentative specifications, prepared with the assistance of workers familiar with the handling of fish and fish products, are to be applied in developing the plant in Chile and these will be adjusted as practical experience is gained.

\section{Future developments}

The operations of the plant in Chile and the investigations in the Massachusetts Institute of Technology will guide further developments in the utilization of fish flour as human food. A uniform product from the plant will be available, which can be used for more extensive tests and trials. Further steps on the part of FAO and UNICEF to encourage the installation of fish-flour plants elsewhere will depend to a large extent on the experience and results so obtained.

Studies with non-deodorized flours are continuing. For flours of this kind simpler and less expensive processing methods are needed than for defatted and deodorized flours.

One point of importance may be noted. The suitable use in human feeding of a locally produced food rich in protein such as fish flour seems a sensible procedure, and any additional supplies of protein of high quality must be welcomed. The present abundance and low price of dried skim milk tends, however, to distract attention from the need to develop local sources of protein and it may be available in large quantities for many years to come.

\section{REFERENCES}

Bender, A. E. \& Miller, D. S. (1953). Biochem. F. 53, vii.

Miller, D. S. \& Bender, A. E. (1955). Brit. F. Nutr. 9, 382. 